\title{
THREE NEW SPECIES OF THE SPIRAL NEMATODE GENUS Helicotylenchus Steiner, 1945 (Nematoda: Hoplolaimidae) FROM VIETNAM
}

\author{
Nguyen Ngoc Chau, ${ }^{1,2}$, Do Tuan Anh ${ }^{1,2}$ \\ ${ }^{1}$ Institute of Ecology and Biological Resources, VAST, Vietnam \\ ${ }^{2}$ Graduate University of Science and Technology, VAST, Vietnam
}

Received 1 February 2019, accepted 5 April 2019

\begin{abstract}
Investigations on entomopathogenic and plant parasitic nematodes in some natural forests in the Ngoc Linh mountain (Quang Nam province) and the Thuong Xuan forest (Thanh Hoa province) revealed three new species of plant parasitic nematodes belonging to the genus Helicotylenchus Steiner, 1945 (Nematoda: Hoplolaimidae). These new species were named Helicotylenchus castanus sp. n., Helicotylenchus madhucus sp. n. and Helicotylenchus digitus sp. n. with morphological characteristics described and illustrated. The new species Helicotylenchus castanus sp.n. is characterized by the highly hemispherical shape of the lip region, extremely short and rounded tail without projection. The second new species Helicotylenchus madhucus sp. $\mathrm{n}$. is characterized by high lip region with 4-5 annuli, hemispherical and not set off from body contour, stylet $31.3-35.9(33.3 \pm 1.3) \mu \mathrm{m}$ long, tail with a short ventral projection and the presence of males in the population. The third new species, Helicotylenchus digitus sp.n. was recognized by broad rounded tail with strong annulated projection in the digital shape, and also the presence of males in population.
\end{abstract}

Keywords: Nematoda, Hoplolaimidae, Helicotylenchus, new species, taxonomy, Vietnam.

Citation: Nguyen Ngoc Chau, Do Tuan Anh, 2019. Three new species of the spiral nematode genus Helicotylenchus Steiner, 1945 (Nematoda: Hoplolaimidae) from Vietnam. Tap chi Sinh hoc, 41(2): 13-27. https://doi.org/10.15625/0866-7160/v41n2.13597.

*Corresponding author email: chaunguyen@iebr.vast.vn

(O)2019 Vietnam Academy of Science and Technology (VAST) 


\title{
BA LOÀI TUYẾN TRÙNG KÝ SINH THỰC VẠT MỚI GIỐNG Helicotylenchus Steiner, 1945 (Nematoda: Hoplolaimidae) TÙ VIẸT NAM
}

\author{
Nguyễn Ngọc Châu ${ }^{1,2, *}$, Đỗ Tuấn Anh ${ }^{1,2}$ \\ ${ }^{1}$ Viện Sinh thái và Tài nguyên sinh vật, Viện Hàn lâm Khoa học và Công nghệ Việt Nam, Việt Nam \\ ${ }^{2} H o ̣ c$ viện Khoa học và Công nghệ, Viện Hàn lâm Khoa học và Công nghệ Việt Nam, Việt Nam
}

Ngày nhận bài 1-2-2019, ngày chấp nhận 5-4-2019

\section{TÓM TÁT}

Khi nghiên cứu tuyến trùng ký sinh và thực vật ở một số khu rừng tự nhiên ở núi Ngọc Linh (tỉnh Quảng Nam) và Thường Xuân (tỉnh Thanh Hóa) đã phát hiện ba loài tuyến trùng ký sinh thực vật mới thuộc giống Helicotylenchus Steiner, 1945 (Nematoda: Hoplolaimida), được đặt tên là Helicotylenchus castanus sp. n., Helicotylenchus madhucus sp. n. và Helicotylenchus digitus sp. n., được mô tả và minh họa bằng ảnh vẽ và ảnh chụp hiển vi. Loài mới Helicotylenchus castanus sp.n. đặc trưng bởi cấu trúc vùng môi cao, bán cầu, đuôi cực ngắn và tròn mà không có mấu. Loài Helicotylenchus madhucus $\mathrm{sp}$. n. đặc trưng bởi vùng môi hình bán cầu với 4-5 vòng cu tin và không tách biệt với đường viền cơ thể, kim hút khỏe, dài 31,3-35,9 $(33,3 \pm 1,3) \mu \mathrm{m}$, tận cùng đuôi có mấu ngắn về phía bụng và có sự hiện diện của con đực trong quần thể. Loài Helicotylenchus digitus sp.n. được phân biệt với các loài khác của giống bởi đuôi tròn rộng với mấu đuôi lớn hình ngón tay ở mút đuôi, có sự hiện diện của con đực trong quần thể.

Từ khóa: Nematoda, Hoplolaimidae, Helicotylenchus, tuyến trùng ký sinh thực vật, khóa định loại, Việt Nam.

*Địa chỉ liên hệ email: chaunguyen@iebr.vast.vn

\section{INTRODUCTION}

With about 230 valid nominal species (Uzma, Nasira, Firoza \& Shahina, 2015), the genus Helicotylenchus Steiner, 1945 (Nematoda: Hoplolaimidae) is one of the most species rich and widely distributed migratory ectoparasitic or semi-endoparasitic nematode genera of the order Tylenchida (sensu Siddiqi, 2000). They are associated with a variety of crops of agricultural importance (Decraemer \& Hunt, 2006; Subbotin et al., 2015). In Vietnam, the genus Helicotylenchus is also the most diverse genus and significant in agriculture and forest ecosystems. Eroshenko et al. (1985) described seven new species of Helicotylenchus from different agriculture crops in Northern provinces of Vietnam. In 2000, Nguyen N. Chau \& Nguyen V. Thanh published a book entitled "Plant Parasitic Nematodes in Vietnam" (Fauna of Vietnam, Vol. 4) in which 160 species of plant parasitic nematodes from agriculture ecosystems of Vietnam were recorded and described. Among them, 30 species of the genus Helicotylenchus were described and illustrated with species identification keys. A 1996-1997 survey on plant parasites associated with natural ecosystems in Vietnam recorded four new species of Helicotylenchus from agricultural and nature forest ecosystems in the Northern and Central Vietnam, of which two species were recorded from agriculture and the other two from forest ecosystems (Nguyen V.T. \& Nguyen N.C. 2001). This newly published description increased the total number of spiral nematodes recorded from Vietnam to 34 species, most of which were recorded from 
agriculture and only two species recorded from forest, and 11 of them were new species.

During more recent survey in 2002-2005 on plant parasitic and entomopathogenic nematodes in natural forests of Central Vietnam, three new species of spiral nematodes, Helicotylenchus were found from soil samples. Herein, they are described and illustrated as Helicotylenchus castanus n. sp., Helicotylenchus madhucus n. sp. and Helicotylenchus digitus $\mathrm{n}$. sp.

\section{MATERIALS AND METHODS}

Survey and sampling: For entomopathogenic nematodes and plant parasitic nematodes from several natural forests in Central Vietnam were conducted during 2002-2005. For each composed sample, $250 \mathrm{ml}$ rhizosphere soil and root within the area of $20 \mathrm{~cm}^{2}$ around tree base was taken using a sampling shovel.

Nematode extraction: Nematodes from $250 \mathrm{ml}$ soil samples were extracted using a modified Cobb's sieving-decanting technique with final use of a sieve with $75 \mu \mathrm{m}$ mesh size for filtering living nematodes. This was followed with static filtering of living nematodes, using a special sieve $80 \mathrm{~mm}$ in diameter and $15 \mathrm{~mm}$ high, including a cylindrical shaft $10 \mathrm{~mm}$ high and three supporting legs $5 \mathrm{~mm}$ high (Nguyen \& Nguyen, 1993). The bottom of the sieve is made of nylon mesh with openings $75 \mu \mathrm{m}$ in size. The sieve containing nematode sediment obtained after decantation was placed in a Petri dish $90 \mathrm{~mm}$ in diameter for stationary filtering of living nematodes. For the filter sieve containing nematode sediment, tap water was added to cover the layer of sediment and the sieve was left for 48 hours at room temperature allowing nematodes to be removed through sieving into the bottom of Petri dish.

Nematodes were killed in hot water at 65 $70^{\circ} \mathrm{C}$, then fixed in Triethanolamin-AlcoholFormalin (TAF) solution and mounted in anhydrous glycerin using the slow method of Hooper and Evans (1993). All morphometrics were performed with a camera lucida drawing tube. Measurements are presented in micrometers (except for ratios) and expressed as the mean \pm standard deviation followed by the range.

All nematode specimens examined were deposited as slides numbered 545TX1 to $545 \mathrm{TX} 4) ; 546 \mathrm{TX} 1$ to $546 \mathrm{TX} 4 ; 691 \mathrm{~N} 1$ to 691NL3 at the Nematode Collection of the Department of Nematology, Institute Ecology and Biological Resources (IEBR), Vietnam Academy of Science and Technology, 18 Hoang Quoc Viet Road, Cau Giay District, Hanoi, Vietnam.

\section{Descriptions}

\section{Helicotylenchus castanus sp. n. (Figs 1-2)}

\section{Measurements}

Holotype female: $615 \mu \mathrm{m} ; \mathrm{a}=17.9 ; \mathrm{b}=$ $5.8 ; b^{\prime}=4.1 ; \mathrm{c}=89.2 ; c^{\prime}=0.5 ; \mathrm{V}=67.6 \% ; \mathrm{O}$ $=41.2$; head diameter $=6 \mu \mathrm{m}$; head height $=$ $3.5 \mu \mathrm{m}$; stylet $=31.5 \mu \mathrm{m}$; stylet knob width $=$ $4 \mu \mathrm{m}$; stylet cone length $=10 \mu \mathrm{m} ;$ DGO $=$ $10 \mu \mathrm{m}$; Exc. Pore $=109.5 \mu \mathrm{m}$; nerve ring $=$ $82.5 \mu \mathrm{m}$; hemizonid $=101.5 \mu \mathrm{m}$.

Paratype females $(\mathrm{n}=16): \mathrm{L}=569-658$ $(610 \pm 30) \mu \mathrm{m} ; \mathrm{a}=17-24.5(21 \pm 2.4) ; \mathrm{b}=$ $4.5-6(5 \pm 0.4) ; b^{\prime}=3.6-4.8(4 \pm 0.3) ; c=$ 63.3-91.2 (77 \pm 9$) ; c^{\prime}=0.5-0.7(0.6 \pm 0.1) ; \mathrm{V}$ $=66.4-70.8(67.6 \pm 1.2) \% ; \mathrm{O}=33.3-42.4$ $(39.3 \pm 2.1)$; head diameter $=4.5-6(5 \pm 0.9)$ $\mu \mathrm{m}$; head height $=3-5(4.1 \pm 0.7) \mu \mathrm{m}$; stylet $=$ 28.5-32.5 $(30 \pm 1) \mu \mathrm{m}$; stylet knob width $=3-$ $5.5(4 \pm 0.9) \mu \mathrm{m}$; stylet cone length $=10-13.5$ $(11 \pm 1.2) \mu \mathrm{m} ; \mathrm{DGO}=9.5-12.5(10.5 \pm 1.1)$ $\mu \mathrm{m}$; Exc. Pore $=95-115(102.5 \pm 6) \mu \mathrm{m}$; nerve ring $=81.5-86.5(83 \pm 1.9) \mu \mathrm{m}$; hemizonid $=95.5-114.5(106 \pm 5.1) \mu \mathrm{m}$.

\section{Morphological characteristics}

Female: Body short and thin, arcuate ventrally to open $\mathrm{C}$-shape after treatment by gentle heat; cuticle finely striated with 1.3-1.4 $\mu \mathrm{m}$ wide annuli at mid-body. Lip region continuous with body contour, hemispherical in shape or rounded with developed labial framework and 4-5 annuli. Stylet strong, conus length $35 \%$ of stylet length. Basal knobs with one side anteriorly convex, the other anteriorly concaved. 


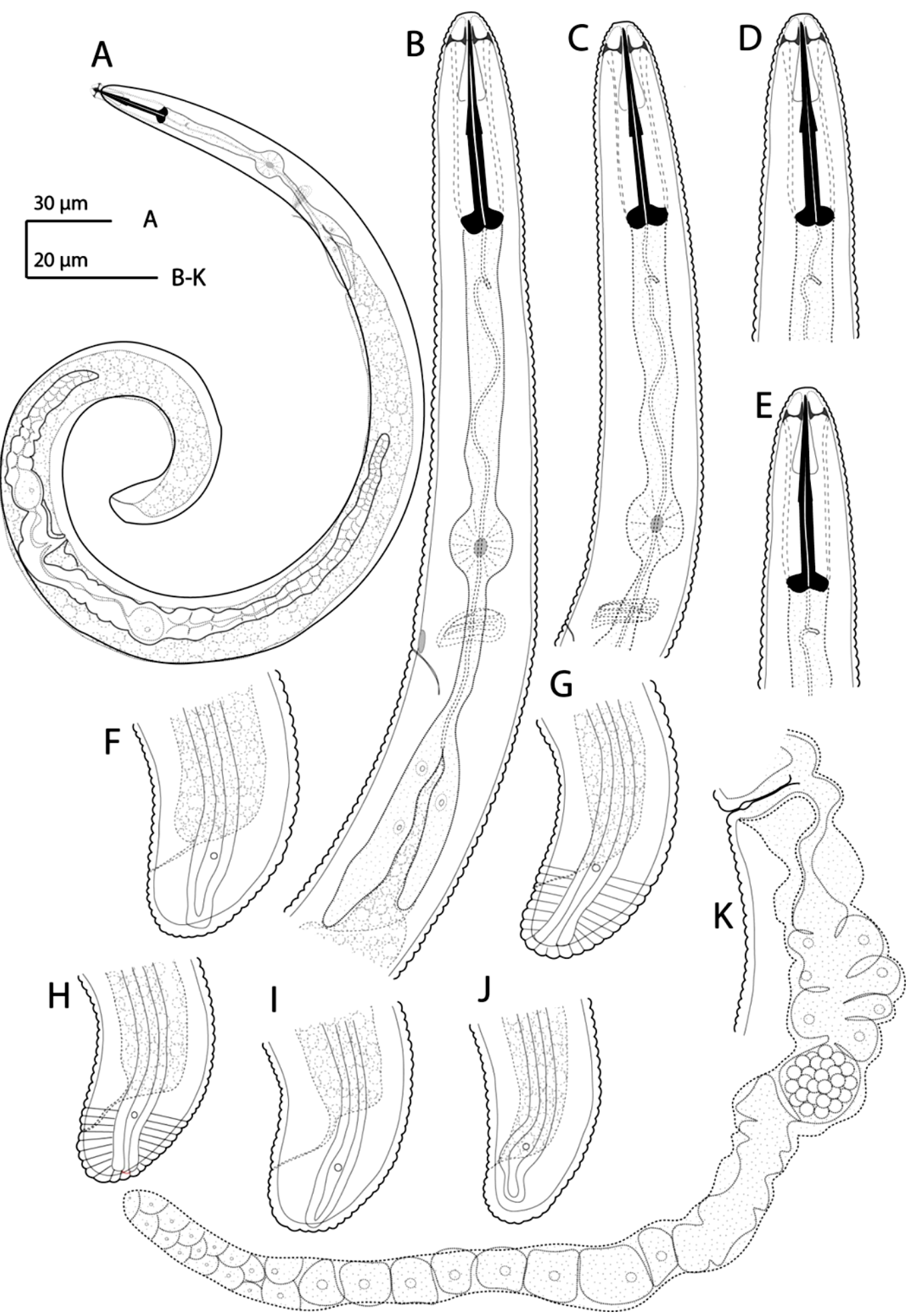

Figure 1. Drawing of Helicotylenchus castanus sp. n. A. Entire female (holotype). B. C. D. Anterior end showing stylet and esophageal region. K. Female posterior genital branch. F. G. H. I. J. Female posterior end with variation of tail terminus, phasmid position and lateral field 

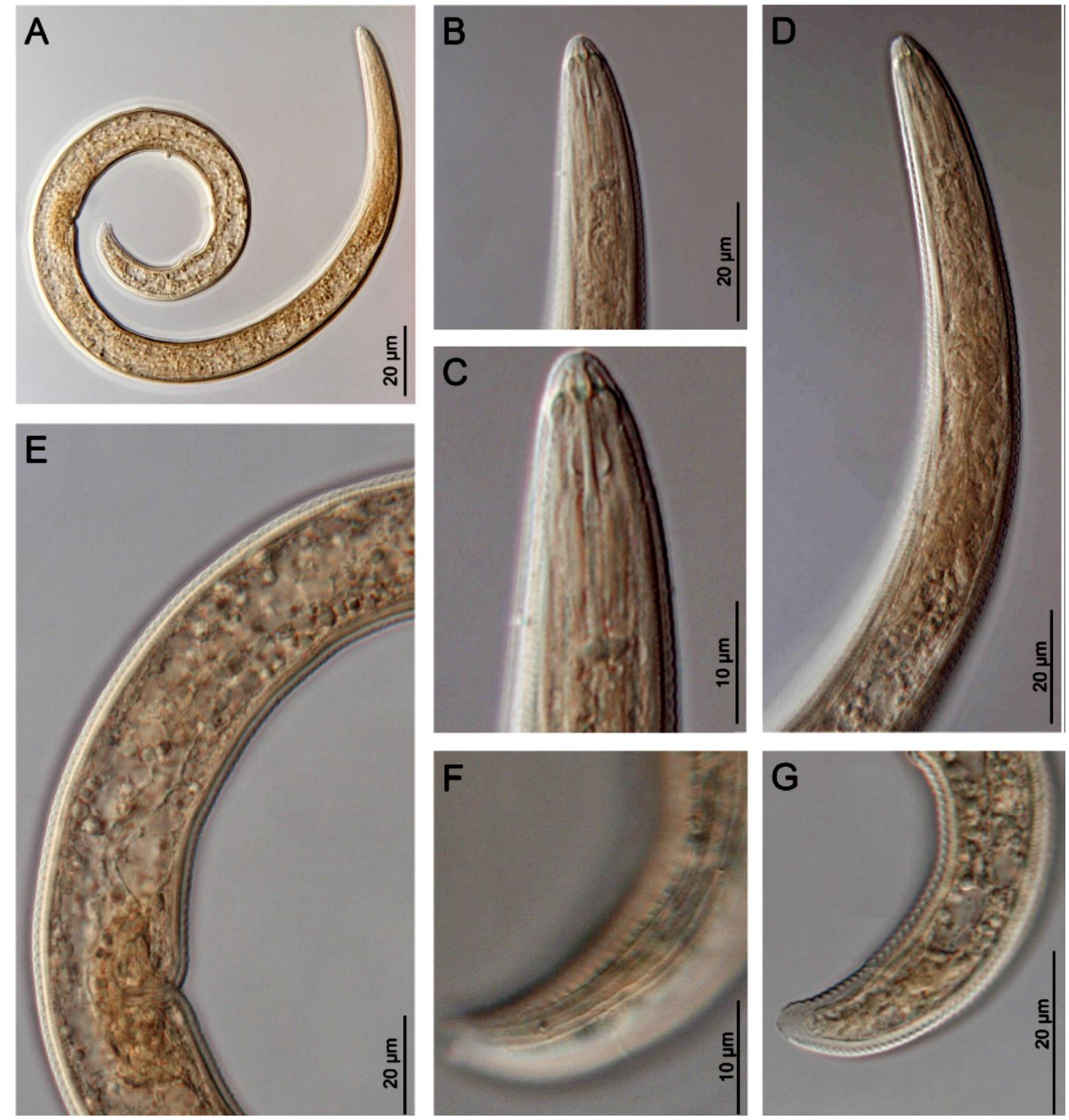

Figure 2. Photomicrographs of Helicotylenchus castanus sp. n. A. Entire female (holotype).

B, C. Anterior end showing stylet. D. Esophageal region. E. Reproduction system.

F. Lateral field showing phasmid. G. Posterior end

Esophagus with well-developed oval metacorpus, esophageal gland 112.7-130.6 (122.6 \pm 6.3) $\mu \mathrm{m}$ long and overlapping intestine ventrally. Nerve ring around isthmus and located anterior excretory pore more than $10-15 \mu \mathrm{m}$. Hemizonid situated at $0-2$ annuli anterior the excretory pore. Lateral field four lines occupying about one fourth of corresponding body diameter, with these lateral fields usually expanded at phasmid region, closing rounded near tail terminal. Reproductive system didelphic amphidelphic 72.5-101.1 (84.5 \pm 9.4) $\mu \mathrm{m}$ long, oocytes usually arranged in one row, vulva a transverse slit in ventral view. Spermatheca oval or rounded and filled with sperms. Round tail, 19.1-29.9 (23.2 \pm 3.3$) \mu \mathrm{m}$ long with 7-11 ventral annuli dorsally convex and without 
mucro. Phasmids pore-like situated at the anus level or 3-4 annuli anterior to anus.

Male: not found.

Type habitat and locality: Helicotylenchus castanus n. sp. was extracted from rhizosphere soil of sweet chestnut (Castanea sativa) in the Thuong Xuan natural Forest, Thanh Hoa province (North Central Coast of Vietnam).

Diagnosis and relationship: Helicotylenchus castanus sp. $\mathrm{n}$. is characterized by the high hemispherical shape of the lip region, short and rounded tail. In morphology, the new species belongs to the group of rounded tail species, including $H$. canadensis Waseem, 1961, H. cavenessi Sher, 1966, $H$. limari Eroshenko et al., 1985, $H$. multicintus (Cobb, 1893) Golden, 1956, $H$. pseudodigonicus Szczygiel, 1970 and $H$. whiteheadi (Ganguly \& Khan, 1987) Firoza \& Maqbool, 1994. The new species, however, differs from all these species by much shorter tail with $c=63-91\left(c^{\prime}=0.5-0.7\right)$, whereas other species $\mathrm{c}=33-65$ and c' index is larger, being 0.8 . In addition, stylet is much longer, being $28-33 \mu \mathrm{m}$ whereas other ones have stylet length below $30 \mu \mathrm{m}$. In addition, one by one comparison showed other differences. For example, compared to $H$. canadensis, the new species has smaller V index (61-66 vs 66.470.8 ), shorter DGO (6-9 vs 9.3-12.4 $\mu \mathrm{m})$, phasmid position (12-3 vs 3-4 ann.) and tail rounded vs. convex-conoid. To $H$. multicinctus, the new species has larger average body length (610 vs 470-530 $\mu \mathrm{m}), \mathrm{c}$ index smaller (35-46 vs 63-91), stylet shorter (22-24 vs 28.5-32.5 $\mu \mathrm{m})$ and phasmid position (10-4 vs 3-4 ann.). To $H$. limari, the new species also differs by body length, stylet length, indeces a, V.

Type specimens: Holotype female and sixteen female paratypes were deposited at the Department of Nematology, Institute Ecology and Biological Resources, Vietnam Academy of Science and Technology, 18 Hoang Quoc Viet Road, Cau Giay District, Hanoi, Vietnam.

Etymology: The species name is derived from the scientific name of the host plant
(Madhuca pasquieri), the Thuong Xuan forest, Thanh Hoa province.

Helicotylenchus madhucus sp. n. (Figs 3-4)

\section{Measurements}

Holotype female: $806 \mu \mathrm{m} ; \mathrm{a}=27.4 ; \mathrm{b}=$ $6.8 ; b^{\prime}=5.3 ; \mathrm{c}=51.3 ; c^{\prime}=0.8 ; \mathrm{V}=60.1 \% ; \mathrm{O}$ $=35.6$; Head diameter $=5.5 \mu \mathrm{m}$; Head height $=3.5 \mu \mathrm{m}$; stylet $=33.5 \mu \mathrm{m}$; stylet knob width $=3.5 \mu \mathrm{m}$; stylet cone $=10.6 \mu \mathrm{m} ; \mathrm{DGO}=8.7$ $\mu \mathrm{m}$; exc. pore $=123 \mu \mathrm{m}$; nerve $\operatorname{ring}=87.5$ $\mu \mathrm{m}$; hemizonid to anterior end $=104 \mu \mathrm{m}$;

Paratype females $(\mathrm{n}=16): \mathrm{L}=637-898$ $(801 \pm 58) \mu \mathrm{m} ; \mathrm{a}=21.3-27.4(24.5 \pm 1.8) ; \mathrm{b}=$ 5.4-7.1 (6.2 \pm 0.5$) ; b^{\prime}=4.3-5.5(4.8 \pm 0.4) ; c$ $=50-78(61.5 \pm 7.8) ; c^{\prime}=0.6-0.8(0.7 \pm 0.1)$; $\mathrm{V}=56.5-62(59 \pm 1.6) \% ; \mathrm{O}=30.6-38.4$ $(33.8 \pm 2.5)$; head diameter $=5.0-7(5.9 \pm 0.6)$ $\mu \mathrm{m}$; head height $=3.5-5.0(4.2 \pm 0.5) \mu \mathrm{m}$; stylet $=31.5-36(33.3 \pm 1.3) \mu \mathrm{m}$; stylet knob width $=3.0-4(3.4 \pm 0.3) \mu \mathrm{m}$; stylet cone length $=9-11.5(10.2 \pm 0.9) \mu \mathrm{m} ; \mathrm{DGO}=7-9$ $(8.0 \pm 0.5) \mu \mathrm{m}$; exc. pore $=103.5-123(116 \pm$ $6)$; nerve ring $=86-90(87.7 \pm 1.4) \mu \mathrm{m}$; hemizonid to anterior end $=101.5-122(111.4$ $\pm 7.8) \mu \mathrm{m}$.

Paratype males $(\mathrm{n}=3): \mathrm{L}=675-731.5$ $(705.9 \pm 28.7) \mu \mathrm{m} ; \mathrm{a}=38.6-43.8(40.4 \pm 2.9)$; $\mathrm{b}=6.4-7.0(6.7 \pm 0.3) ; \mathrm{b}^{\prime}=6.4-6.9(6.6 \pm$ $0.3)$; c $=88.8-134.2(109.2 \pm 23.1)$; c' $=0.3-$ $0.4(0.4 \pm 0.1) ; \mathrm{O}=78.1-94.8(85.2 \pm 8.6)$; head diameter $=5-5.5(5.5 \pm 0.1) \mu \mathrm{m}$; head height $=3.5-4(3.9 \pm 0.3) \mu \mathrm{m}$; stylet $=20-23$ $(21 \pm 1.5) \mu \mathrm{m}$; stylet knob width $=3.5-4(3.5$ $\pm 0.2) \mu \mathrm{m}$; stylet cone $=8.5-90(8.6 \pm 0.2)$ $\mu \mathrm{m} ; \mathrm{DGO}=6-6.5(6.3 \pm 0.2) \mu \mathrm{m} ;$ exc. pore $=$ $75.5-94.5(84 \pm 9.6) \mu \mathrm{m}$; nerve ring $=75.5-$ $82(78.5 \pm 3) \mu \mathrm{m}$; hemizonid $=75-94(84 \pm$ 9.5) $\mu \mathrm{m}$; spicule $=23.6-23.9(23.8 \pm 0.2) \mu \mathrm{m}$; gubernaculum $=7.4-8.3(7.7 \pm 0.5) \mu \mathrm{m}$.

\section{Morphological characters}

Female: Body short and thin, 16.4-19.7 $(18.0 \pm 1.0) \mu \mathrm{m}$ wide at mid-body, usually Cshaped upon fixation. Cuticle distinctly striated with $0.9-1.8(1.4 \pm 0.3) \mu \mathrm{m}$ wide annuli at midbody. Lateral field with four incisures occupying $1 / 3$ of body diameter and elongated to terminal of tail. Inner two 
incisures not fused at terminal of tail. Lip region hemispherical not set off from rest of body contour, $5.0-6.9(5.9 \pm 0.6) \mu \mathrm{m}$ wide and 3.4-5.0 (4.2 \pm 0.5$) \mu \mathrm{m}$ high, with developed labial framework and 4-5 annuli. Stylet robust with one rounded and one anteriorly flattened basal knob 3.0-3.9 (3.4 \pm 0.3) $\mu \mathrm{m}$ wide. Dorsal esophageal gland located posterior basal knob at 25-30\% stylet length. Esophagus 105.3-110.8 (108.3 \pm 1.6$)$ $\mu \mathrm{m}$ long, with long procorpus and isthmus and oval metacorpus. Hemizonid distinct, usually about $1-1.5$ annuli wide and situated 1-2 annuli anterior to excretory pore.
Reproductive system didelphic amphidelphic, well developed with anterior branch 76.0$87.6(80.6 \pm 4.3) \mu \mathrm{m}$ long and posterior branch 83.4-100.6 (92.9 \pm 5.8) $\mu \mathrm{m}$ long, oocytes usually arranged in one row, but anterior in two rows until the cap cell. Vulva a transverse slit. Spermatheca axial, rounded, 9.2-12.4 $\mu \mathrm{m}$ diameter with sperm. Tail short 5-7.5 (6.8 \pm 0.7$) \mu \mathrm{m}$ and ventrally arcuate, with 5-8 annuli and terminated by broad ventral projection. Phasmids distinct, porelike, usually situated at $2-10$ annuli posterior to anus level.

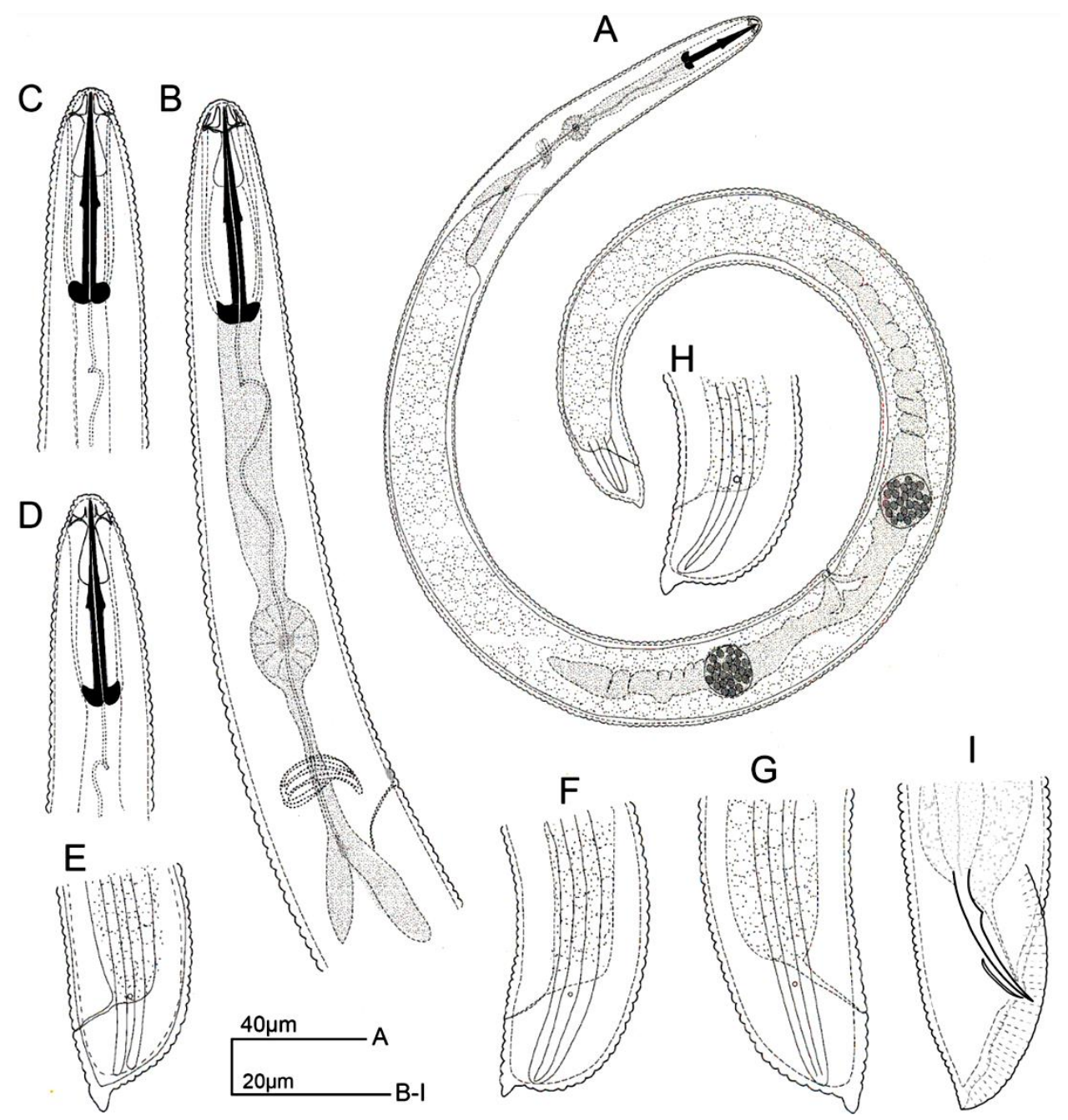

Figure 3. Drawing pictures of Helicotylenchus madhucus sp. n. A. Entire female (holotype). B. Oesophageal region. C-D. Anterior end showing stylet. E-G Variation of tail showing phasmid and lateral field 

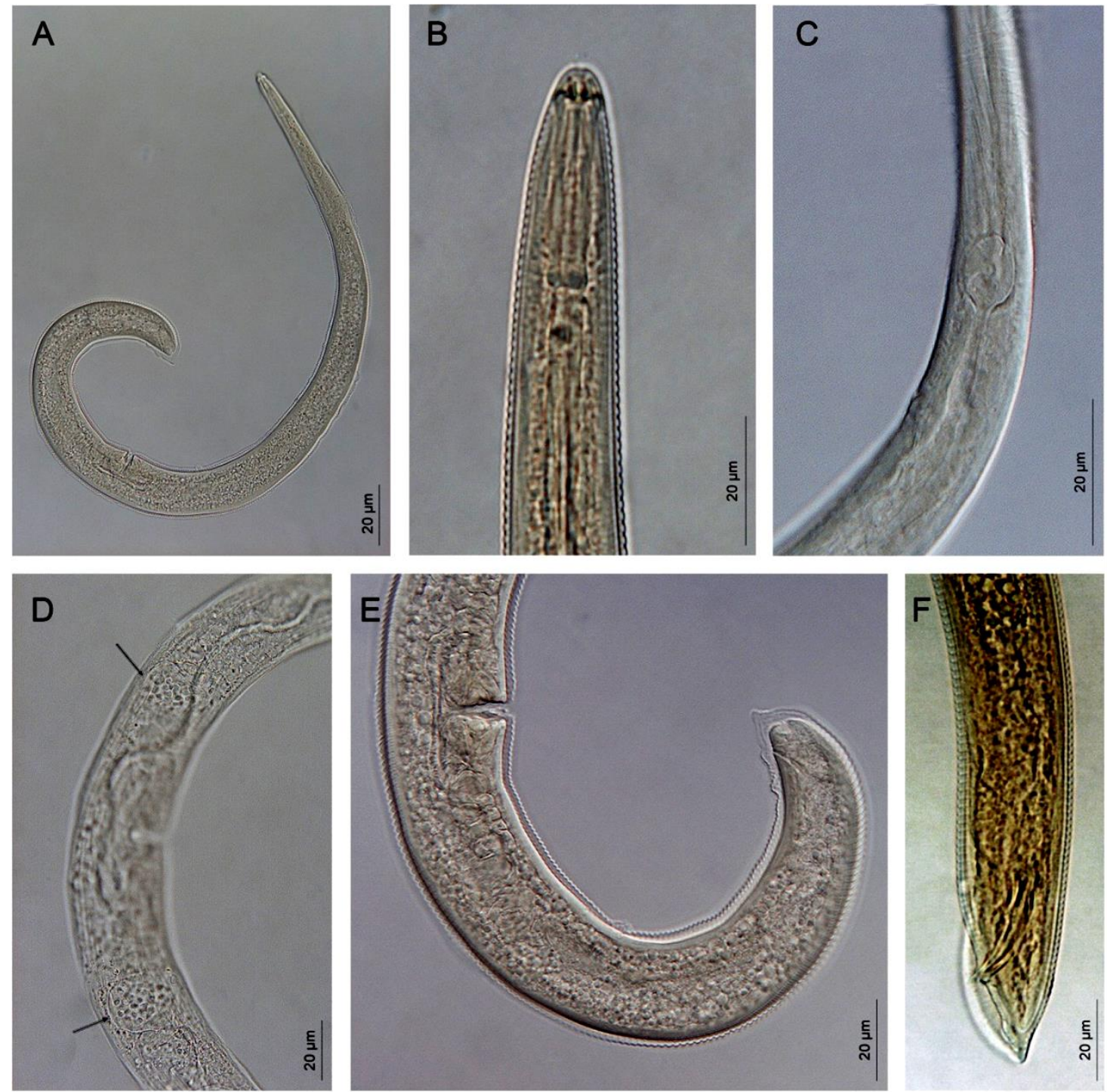

Figure 4. Microphotographs of Helicotylenchus madhucus sp. nov. A. Entire female (Paratype).

B. Anterior body end. C. Oesopageal region showing median bulb and esophageal glands.

D. Vulval region showing portion of two genital branches with spermatheca.

E. Female posterior body with short tail

Male: Habitus C-shape or straight. Lip region hemispherical, $5.5-6(5.5 \pm 0.1) \mu \mathrm{m}$ wide and 3.5-4 (3.9 \pm 0.3$) \mu \mathrm{m}$ high. Labial framework extending 3-5 annuli posterior from basal plate. Stylet knobs 3-3.5 (3.5 \pm 0.2$)$ $\mu \mathrm{m}$ anterior faces flattened or indented. Ventral overlap of esophageal lobes 14.5-16.5 $(15.5 \pm 1.1) \mu \mathrm{m}$ long. Excretory pore situated opposite posterior part of isthmus. Hemizonid situated 1-2 annuli anterior to excretory pore.
Testis single, anteriorly outstretched and 194$234 \mu \mathrm{m}$ long. Spicule moderately slender with a narrow distal portion bearing a ventral flange and an expanded tip. Gubernaculum curved in lateral view. Bursa crenate, extending from opposite the proximal end of the retracted spicule to the tail terminus. Phasmids pre-cloacal 14-16 annuli from the anterior cloacal lip. 
Type habitat locality: Nematode specimens were collected from rhizosphere soil of bullet wood (Madhuca pasquieri) in the Thuong Xuan forest, Thanh Hoa province (in North Central Coast of Vietnam).

Diagnosis and relationnship: The new species, Helicotylenchus madhucus sp.n. can be recognized by short tail with a broad ventral projection. Lip region with 4-5 annuli, hemispherical not set off from body contour. Stylet strong with knob rounded in one side to slightly anterior concave in other side. In morphology, Helicotylenchus madhucus sp.n. is close to $H$. atlanticus Fernandez, Razjivin, Ortega \& Quincosa, 1980, H. canalis Sher, 1966, H. notabilis Eroshenko \& Nguyen, 1981 and $H$. crassatus Anderson, 1973. To $H$. atlanticus, the new species rather differs by longer body $(637-898 \mu \mathrm{m}$ vs $620-710 \mu \mathrm{m})$ and stylet (31-36 vs $26-27.4)$, but smaller $\mathrm{V}$ (56-62 vs $65-66 \%$ ). To $H$. notabilis and $H$. crassatus, the new species differs by longer stylet (31-36 vs 21-23 and 26-30 $\mu \mathrm{m}$ ), smaller V value (56-62 vs 62-66 and 61-74), head anulus (4-5 vs. and 4 annuli). In addition, the new species differs from others by the presence of male in population.

Type specimens: Holotype female, 16 paratype females and 3 males are deposited at the Nematode Collection of the Department of Nematology, Institute of Ecology and Biological Resources (IEBR), Vietnam Academy of Science and Technology, 18 Hoang Quoc Viet Road, Cau Giay District, 122100 Hanoi, Vietnam.

Etymology: The species name is derived from the scientific name of the host plant (Madhuca pasquieri) the Thuong Xuan forest, Thanh Hoa province.

\section{Helicotylenchus digitus sp. n. (Figs 5-6)}

\section{Measurements}

Holotype female: $550 \mu \mathrm{m} ; \mathrm{a}=27.4 ; \mathrm{b}=$ $5.7 ; \mathrm{b}^{\prime}=4.8 ; \mathrm{c}=79.7 ; \mathrm{c}^{\prime}=0.8 ; \mathrm{V}=61.2 \% ; \mathrm{O}$ $=53.1 ; \mathrm{m}=43.8$; head diameter $=6 \mu \mathrm{m}$; head height $=4.5 \mu \mathrm{m}$; stylet $=22.5 \mu \mathrm{m}$; stylet knob width $=4 \mu \mathrm{m}$; stylet cone length $=10 \mu \mathrm{m}$; exc pore $=96 \mu \mathrm{m} ;$ nerve ring $=75.5 \mu \mathrm{m}$; hemizonid $=82.5 \mu \mathrm{m}$.
Paratype females $(\mathrm{n}=15): \mathrm{L}=535-550$ $(540 \pm 6.2) \mu \mathrm{m} ; \mathrm{a}=24.1-28.3(26.0 \pm 1.8) ; \mathrm{b}$ = 5.4-7.3 (6.1 \pm 0.7$) ; b^{\prime}=4.2-4.8(4.5 \pm 0.3)$; $\mathrm{c}=55.1-80.8(73.3 \pm 10.9) ; \mathrm{c}^{\prime}=0.8-0.9(0.8$ $\pm 0.1) ; \mathrm{V}=58.9-63.1(61.8 \pm 1.8) \mu \mathrm{m} ; \mathrm{O}=$ 48.5-58 (53.9 \pm 3.4$) ; \mathrm{m}=41.6-47.7(43.9 \pm$ 2.3); stylet $=21.5-24(22.4 \pm 0.9) \mu \mathrm{m}$; stylet knob width $=3.5-4.5(4.1 \pm 0.3) \mu \mathrm{m}$; stylet cone length $=9-10.5(9.8 \pm 0.7) \mu \mathrm{m}$; exc. pore $=86-92(89.6 \pm 2.3) \mu \mathrm{m}$; nerve ring $=$ $73-80(75.9 \pm 2.4) \mu \mathrm{m}$; hemizonid $=82.5-90$ $(86.5 \pm 3) \mu \mathrm{m}$.

Paratype males $(\mathrm{n}=3): \mathrm{L}=446.5-494$ $(466.6 \pm 24.5) \mu \mathrm{m} ; \mathrm{a}=24-28(26.1 \pm 2.1) ; \mathrm{b}=$ $5.3-6.0(5.7 \pm 0.5) ; b^{\prime}=4.6-4.8(4.7 \pm 0.1) ; c=$ $32.3-37.1(34.0 \pm 2.7)$; c' $=1.1-1.2(1.1 \pm 0.1)$; $\mathrm{O}=43.4-47.4(45.4 \pm 2.8)$; head diameter $=$ 60-6.5 $(6 \pm 0.3) \mu \mathrm{m}$; head height $=4.5-5(4.6$ $\pm 0.1) \mu \mathrm{m}$; stylet $=19.5-23(21.5 \pm 2) \mu \mathrm{m}$; stylet knob width $=4-5(4.5 \pm 0.5) \mu \mathrm{m}$; stylet cone length $=8.5-9(8.5 \pm 0.3) \mu \mathrm{m}$; exc. pore $=$ 75-76.5 (7.6 \pm 1.1$) \mu \mathrm{m}$; nerve ring $=72.5-73.5$ $(73 \pm 0.8) \mu \mathrm{m}$; hemizonid $=73.5-74.5(74 \pm$ $0.8) \mu \mathrm{m}$; spicule $=20.8-22.3(21.6 \pm 0.8) \mu \mathrm{m}$; gubernaculum $=6.6-7(6.8 \pm 0.2) \mu \mathrm{m}$.

\section{Morphological characters}

Female: Habitus spiral when relaxed. Cuticle coarsely annulated, annuli 1.1-1.4 $(1.3 \pm 0.2) \mu \mathrm{m}$ wide at mid-body. Lateral fields $4.2-5.1 \mu \mathrm{m}$ wide and $20-30 \%$ of body diameter. Lip region almost conical, truncate, continuous with body contour and marked by four distinct annuli, with dimension of 5.5-6.5 $(6.3 \pm 0.4) \mu \mathrm{m}$ wide at base and 4-5 (4.4 \pm 0.2$)$ $\mu \mathrm{m}$ high. Cephalic framework strongly sclerotized, its outer margins extending posteriorly 1-2 annuli from basal plate. Stylet robust with knobs well developed, with flattened anterior surfaces, 3.7-4.4 (4.1 \pm 0.3$)$ $\mu \mathrm{m}$ across. Orifice of dorsal pharyngeal gland located more than one half of stylet length from knobs. Median bulb oval, gradually enlarging with moderately developed valve. Nerve ring 73.5-79.5 (76 \pm 2.4$) \mu \mathrm{m}$ from anterior end of body. Hemizonid generally distinct, one to two body annuli anterior to excretory pore. Reproductive system didelphic-amphidelphic with both branches about equally developed, length of anterior 
branch 99.5-106 (102.4 \pm 3.2) $\mu \mathrm{m}$ and posterior branch 94.2-104.5 (101.0 \pm 4.5$) \mu \mathrm{m}$. Spermatheca rounded, 8.5-10 $(9.2 \pm 0.8) \mu \mathrm{m}$ in diameter, full of sperms. Vagina with uniformly thin wall, 7.5-8.5 $(8.0 \pm 0.4) \mu \mathrm{m}$ long and about $1 / 3$ to $1 / 2$ of the corresponding body diameter. Tail short, with 6-11 annuli, conoid, convex on the dorsal side, and flat in the ventral side with a sub-digitate peg-like terminus. Phasmids conspicuous, five to six annuli anterior to level of anus.

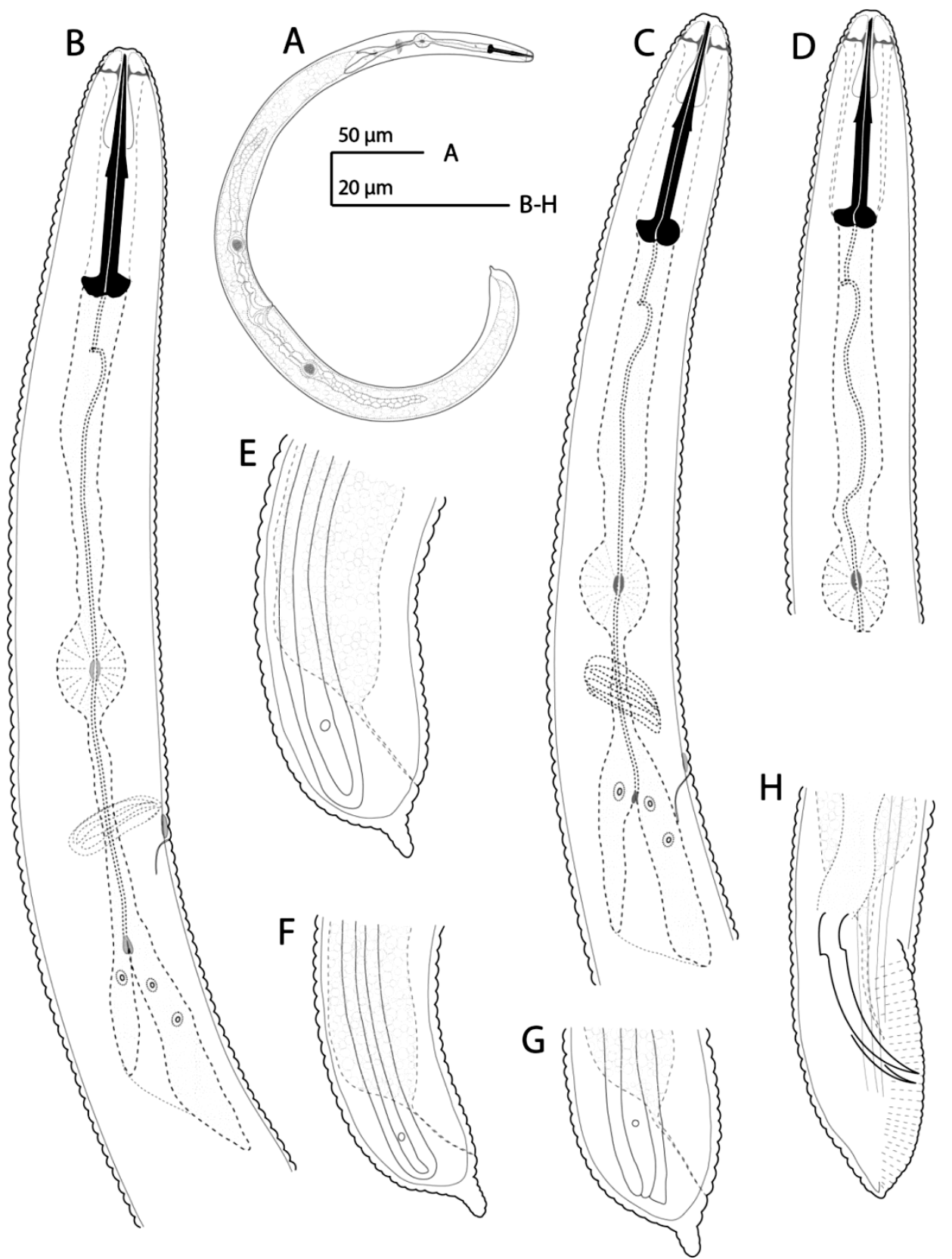

Figure 5. Drawing of Helicotylenchus digitus sp. n. A. Entire female. B. Anterior end. C-D.

Oesopageal region showing stylet. E.F.G. Variation of female tails showing phasmid and lateral field. $\mathrm{H}$. Male tail 

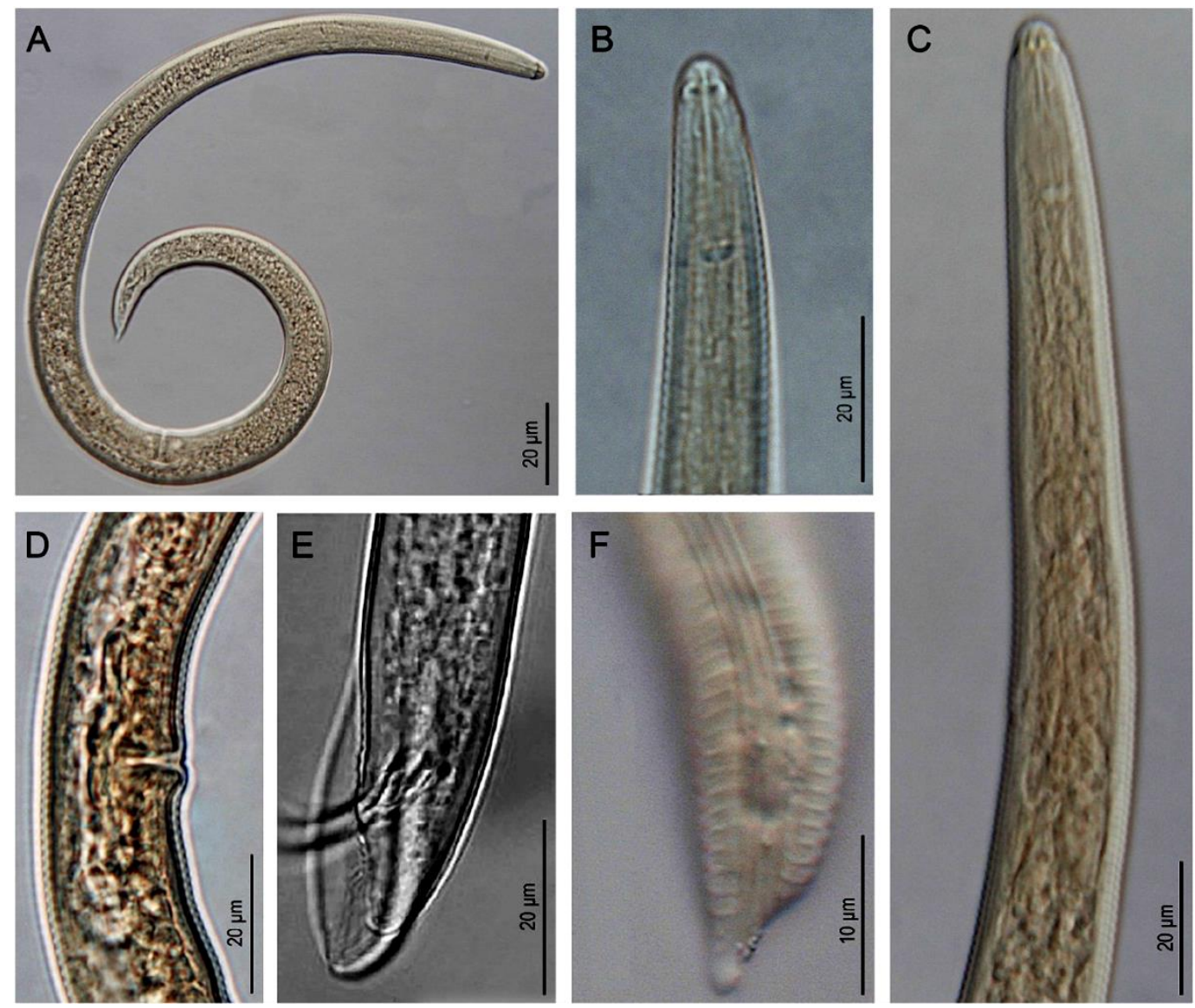

Figure 6. Microphotographs of Helicotylenchus digitus sp. now. A. Entire female (holotype).

B. Anterior end. C. Oesopageal region showing stylet. D. Reproduction system. E. Male tail.

F. Female tail. G, H. Female tail showing phasmid and laterial field

Male: Body ventrally arcuate or straight when killed by heat. Lip region anteriorly flattened with rounded sides, continuous with the body, 6-6.5 (6.0 \pm 0.3$) \mu \mathrm{m}$ wide and 4.5-5 $(4.6 \pm 0.1) \mu \mathrm{m}$ high. Labial framework extending 4-5 annuli posterior from basal plate. Stylet knobs $4-5(4.4 \pm 0.4) \mu \mathrm{m}$ anterior faces flattened or indented. Orifice of dorsal oesophageal gland located 10-11 $(10.5 \pm 0.8)$ $\mu \mathrm{m}$ behind stylet base. Oesophageal glands overlapping the intestine, with the longest overlap ventrally situated, 16-17.5 (16.7 \pm 1.2$)$ $\mu \mathrm{m}$ in length. Excretory pore situated opposite posterior part of isthmus. Hemizonid not prominent, occupying about two body annuli. Lateral field about $1 / 4$ of mid-body diameter with four incisures. Testis single, anteriorly outstretched and 129-158 $\mu \mathrm{m}$ long. Spicule has a narrow distal portion bearing a ventral flange and an expanded tip. Gubernaculum curved in lateral view. Bursa crenate, extending from opposite the proximal end of the retracted spicule to the tail terminus. Phasmids pre-cloacal 5-7 annuli from the anterior cloacal lip.

Type habitat and locality: Helicotylenchus digitus $\mathrm{n}$. $\mathrm{sp}$. was extracted from rhizosphere soil of wood tree (non-identified name) at the Ngoc Linh mountain forest, Quang Nam Province (Central Vietnam).

Diagnosis and relationship: The new species, Helicotylenchus digitus sp.n. can be recognized by broad tail with strong annulated projection. Lip region almost conical, truncate, and continuous with four distinct annuli. In 
morphology, the new species is most close to H. inifatis Fernandez, Razjivin, Ortega \& Quincosa, 1980, H. gerti Marais, Mekette \& Tiedt, 2005, H. similis Fernandez, Razjivin, Ortega \& Quincosa (1980), H. amplius Anderson \& Eveleigh (1981) and $H$. nigeriensis Sher (1966). The new species, however, differs from all these species by smaller body (535-550 vs. 710-750, 520-680, 690-890 and 690-860 $\mu \mathrm{m})$. To $H$. inifatis, $H$. amplius and $H$. nigeriensis, the new species has shorter stylet (21.5-23.5 vs. $27-33 \mu \mathrm{m})$.
Type specimens: Holotype female, 15 female paratypes and 3 allotype males are deposited at the Nematode Collection of the Department of Nematology, Institute Ecology and Biological Resources (IEBR) Vietnam Academy of Science and Technology, 18 Hoang Quoc Viet Road, Cau Giay District, 122100 Hanoi, Vietnam.

Etymology: The species name is derived from the digitate shape of the nematode tail terminus.

\section{Updated key to the species of genus Helicotylenchus from Vietnam}

1 - Tail hemispherical or broad conical, no projection.................................

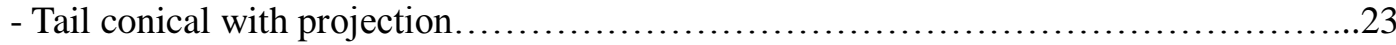

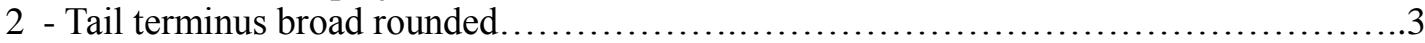

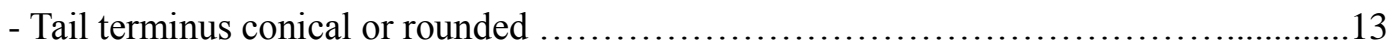

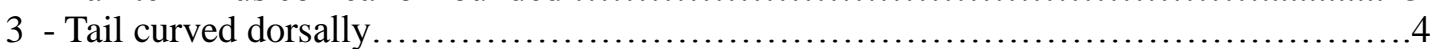

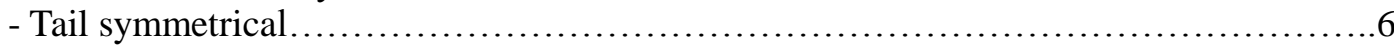

4 - Stylet $23 \mu \mathrm{m}$, phasmid anal level................................... vietnamiensis

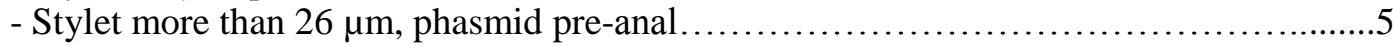

5 - Stylet 29-33 $\mu \mathrm{m}$, phasmid pre-anal 3-4 annules....................... castanus $\mathrm{n}$. sp.

- Stylet 27-29 $\mu \mathrm{m}$, phasmid pre-anal 11-17 annules................................. concavus

6 - Phasmid pre-anal................................................................... 7

- Phasmid post-anal 3-5 annules .................................................... ferus

7 - Stylet knobs rounded or flattened anteriorly, phasmid pre-anal 4 annules...... H. limarius

- Stylet knobs concave anteriorly, phasmid pre-anal 6-14 annules..........................8

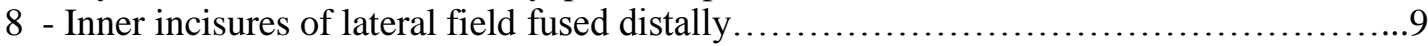

- Inner incisures of lateral field not fused distally................................... 10

9 - Stylet 25-28 $\mu \mathrm{m}$, phasmid pre-anal 9-13 annules................................... dignus

- Stylet 24.5-25 $\mu \mathrm{m}$, phasmid pre-anal 5-9 annules......................... rotundicauda

10 - Stylet $22-24 \mu \mathrm{m}$, male present....................................... multicinctus

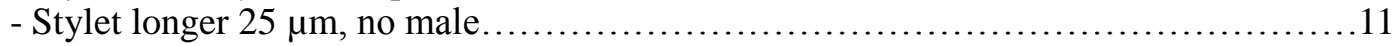

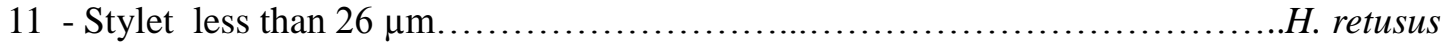

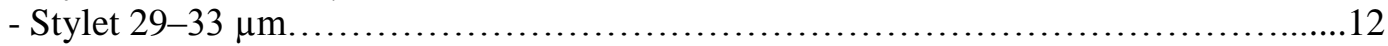

12 - Head truncate, phasmid pre-anal 3 or post-anal 2 annules.................... canadensis

- Head hemispherical, phasmid pre-anal 5-11 annules.......................

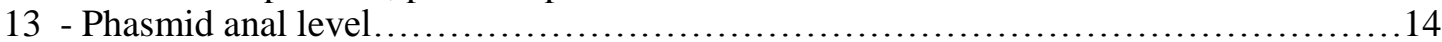

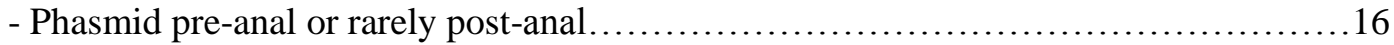

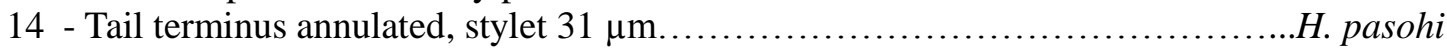

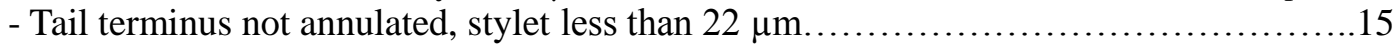

15 - Lip region not annulated or indistinct, inner incisures of lateral field fused distally.........

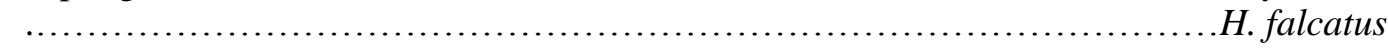

- Lip region annulated, inner incisures of lateral field not fused distally..........H. curvatus

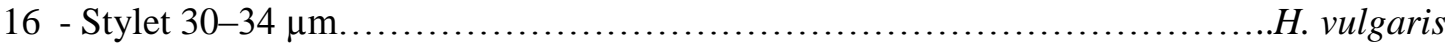

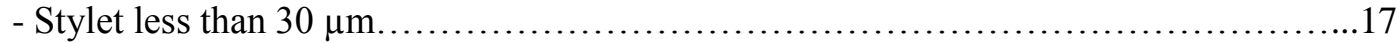

17 - Spermatheca functional, male present.......................................... exallus

- Spermatheca non functional, no male......................................... 18 


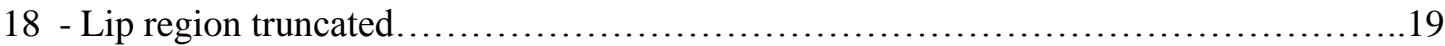

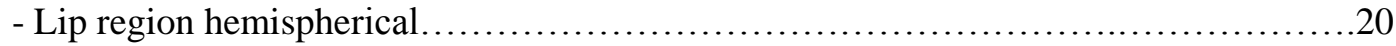

19 - Stylet knobs anterior flattened, phasmid 1-5 pre-anal to 3 post-anal annules

- Stylet knobs rounded to sloping backward, phasmid post-anal 5-6 annules

H. digonicus

H. magnification

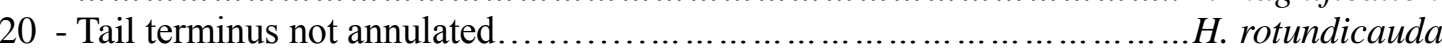

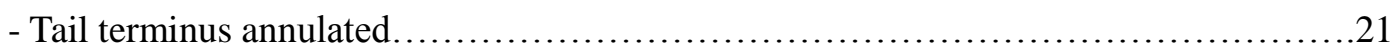

21 - Stylet 23-24 $\mu \mathrm{m}$, inner incisures of lateral field not fused distally................ caribensis

- Stylet more than $24 \mu \mathrm{m}$, inner incisures of lateral field fused distally..................22

22 - Phasmid post-anal 3-4 annules............................................. indicus

- Phasmid pre-anal 4-6 annules......................................... cavenessi

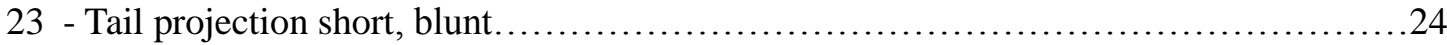

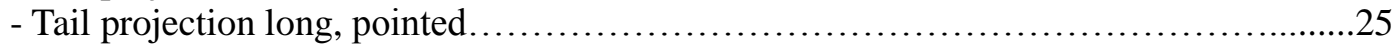

24 - Stylet 25-28 $\mu \mathrm{m}$, inner incisures of lateral field not fused distally... ............ H. crastinus

- Stylet $21-23 \mu \mathrm{m}$, inner incisures of lateral field fused distally............... H. notabilis

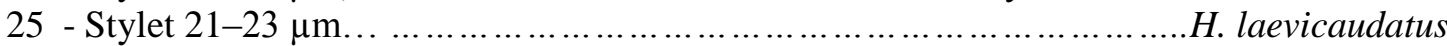

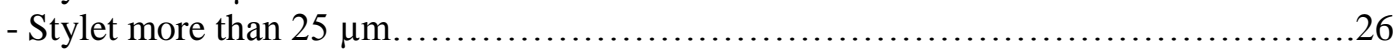

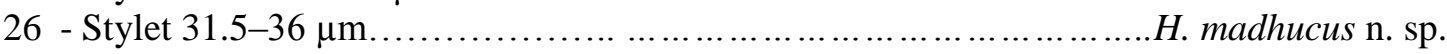

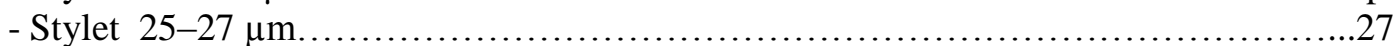

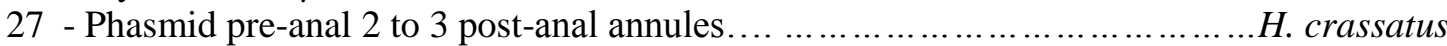

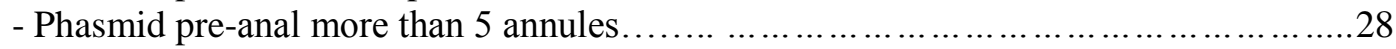

28 - Tail terminus concave............................................... crenacauda

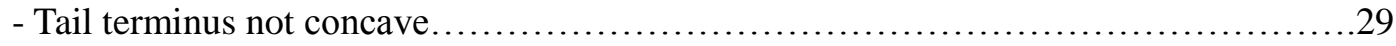

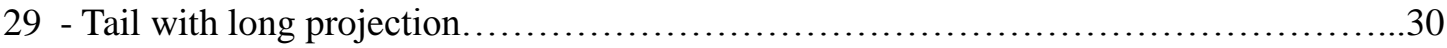

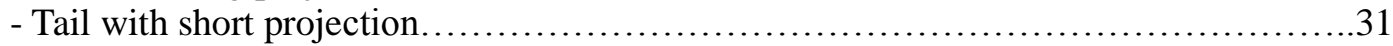

30 - Tail projection digit-shaped, annulated................................. digitus $\mathrm{n}$. sp.

- Tail projection pointed, not annulated............................................ marinus

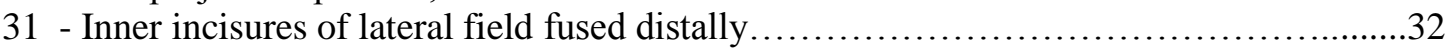

- Inner incisures of lateral field not fused distally..................................... 33

32 - Body $680-840$ long, lip region truncated..................................... cornurus

- Body 540-590 long, lip region hemispherical.................................... bambesae

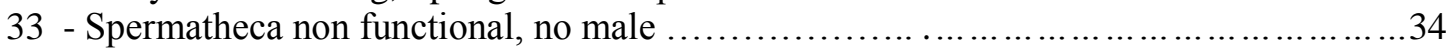

- Spermatheca functional, male present ................................... erythrinae

34 - Phasmid pre-anal 3-11 annules.........................................................

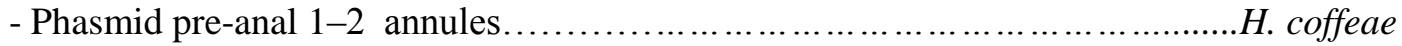

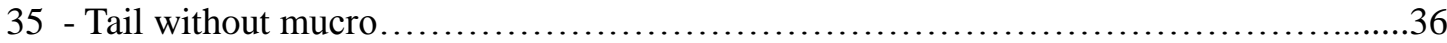

- Tail with mucro................................................... paramucronatus

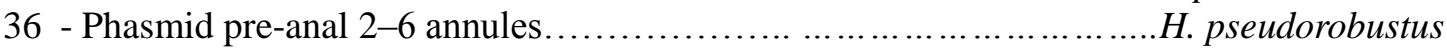

- Phasmid pre-anal 7-11 annules........................................ dihystera

Acknowledgements: This work was funded by the Vietnam National Foundation of Science and Technology Development (NAFOSTED) through project number 106.05-2019.02. The authors thank Prof. W. Decraemer (UGent) for English correction and valuable suggestions.

\section{REFERENCES}

Anderson R. V., 1979. A supplemental key to species of Helicotylenchus Steiner, 1945 (Nematoda: Hoplolaimidae) described since 1972 and a description of $H$. oscephalus n. sp. Canadian Journal of Zoology, 57: 337-342. 
Anderson R. V., Eveleigh E. S., 1982. Description of Helicotylenchus amplius $\mathrm{n}$. sp. and a key to the Canadian species of the genus (Nematoda: Hoplolaimidae). Canadian Journal of Zoology, 60, 318-321.

Eroshenko A. S. \& Nguyen V. T., 1981. Ectoparasitic nematodes of pineapple Plantations in nothern and central provinces of Vietnam. In Free living and Plant parasitic nematodes fauna in oriental regions. USSR Acad. Sci., Vladivostok: 28-34 (in Russian).

Eroshenko A. S., Nguyen N. C, Nguyen V. T. \& Doan C., 1985. Parasitic Phytonematodes of Nothern Vietnam. USSR Acad. Sci. Leningrad: 128 pp (in Russian).

Fernandez M., Razjivin A., Ortega J. \& Quincosa A., 1980. New species of Helicotylenchus (Nematoda: Hoplolaiminae) associated with rice cultivation in Cuba. Poeyana, Instituto de Zoologia, 202: 27.

Firoza K. \& Maqbool M. A., 1994. A diagnostic compendium of the genus Helicotylenchus Steiner, 1945 (Nematoda: Hoplolaimidae). Pakistan Journal of Nematology 12, 11-50.

Fortuner R., 1987. A reappraisal of Tylenchina (Nemata). 8. The family Hoplolaimidae Filipjev, 1934. Revue Nematologie, 10(2): 219-232.

Hooper D. J. \& Evans K., 1993. Extraction, identification and control of plant parasitic nematodes. In: Evans K., Trudgill D. L. \& Webster J. M. (Eds). Plant Parasitic Nematodes in Temprate Agriculture. Wallingford, UK, CABI International, 1-59.

Manohar L. \& Khan E., 1993. On the taxonomic status of species of Helicotylenchus Steiner, 1945. I. Having a digitale type tail terminus from India. Indian Journal of Nematology 23, 110-117.

Marais M., Mekete T. \& Tetdt L. R., 2005. Description of Helicotylenchus gerti sp. n. and new records of some species of Helicotylenchus (Steiner, 1945) from
Ethiopia (Nematoda: Hoplolaimidae). Journal of Nemathology Morphology \& Systematics, 8: 39-49.

Nguyen N. C \& Nguyen V. T., 2000. Fauna of Vietnam. Vol. 4, Plant Parasitic Nematodes in Vietnam. Scientific and Technic Publising, Hanoi: 402 pp.

Nguyen V. T. \& Nguyen N. C., 2001. Four spiral nematode species of Helicotylenchus from Vietnam. Advances in Natural Sciences, 2: 77-88.

Rashid A. \& Khan A. M., 1974. Two new species of genus Helieotylenehus Steiner, 1945 from India with a redescription of $H$. solani Rashid, 1972 (Nematoda: Hoplolaiminae). Indian Journal of Nematology, 2: 123-128.

Shamsi M. A., 1973. Taxonimic notes on the genus Helicotylenchus Steiner, 1945 (Nematoda: Rotylenchinae) with a proposal for Zimmermannia n. sub-genus. Proc. Natn. Acad. Sci., Indian Biological Sciences: 43,80

Sher S. A., 1966. Revision of the Hoplolaiminae (Nematoda). VI. Helicotylenchus Steiner, 1945. Revue Nematologica, 12: 1-56.

Siddiqi M. R., 1972. On the genus Helicotylenchus Steiner, 1945 (Nematoda: Tylenchida) with descriptions of nine new species. Revue Nematologica, 18: 74-91.

Tarjan A. C., (1964). Two new mucronatetailed spiral nematodes (Helicotylenchus: Hoplolaaimidae). Revue Nematologica (1964): 185-191.

Tarjan A. C., 1964. Two new mucronatetailed spiral nematodes (Helicotylenchus: Hoplolaaimidae). Revue Nematologica, 10: 185-191.

Waseem M., 1961. Two new species of the genus Helicotylenchus Steiner, 1945 (Nematoda: Hoplolaiminae). Canadian Journal of Zoology 39: 505-509, https://doi.org/10.1139/z61-054

Uzma I., Nasira K., Firoza K. \& Shahina F., 2015. Review of the genus 
Helicotylenchus Steiner, 1945 (Nematoda: Hoplolaimidae) with updated diagnostic compendium. Pakistan Journal of Nematology, 33: 115-160

Van Den Berg J., 1975. South African Hoplolaiminae. genus
4. The
Helicotglenchus Srteiner. Phytophylactica (1975): 35-52.

Whitehead A. G., 1958. Rotylenchoides brevis n. g., n. sp. (Rotylenchoidinae $\mathrm{n}$. subfam: Tylenchida). Revue Nematologica, 3: 327-331. 